\title{
Hydrogen Gas Production from Tannery Wastewater by Electrocoagulation of a Continuous Mode with Simultaneous Pollutants Removal
}

\author{
Abdalhadi Deghles*, Ugur Kurt \\ Department of Environmental Engineering, Yildiz Technical University, 34349 Istanbul, Turkey.
}

\begin{abstract}
The performance of a continuous electrocoagulation (EC) process was investigated for tannery wastewater treatment using aluminum and iron electrodes. The effects of the operating parameters, such as current density, $\mathrm{pH}$ of solution and inlet flow rate, on pollutants removal efficiency and recovery of hydrogen gas were investigated in order to optimize process performance. In the case of aluminum electrodes, The results showed that for tannery wastewater with an influent $\mathrm{pH}$ adjusted at about 6 , the use of a current density of 14 $\mathrm{mA} / \mathrm{cm}^{2}$, and an EC time of $125 \mathrm{~min}$, gave access to pollutants (COD, Color, Cr, and $\mathrm{NH}_{3}-\mathrm{N}$ ) removal efficiency 73, 94, 100 and 51\%, respectively. The energy yield of harvested hydrogen was $16 \%$ of the electrical energy demand of the electrocoagulation process. However, in the case of iron electrodes, with effluent $\mathrm{pH}$ adjusted at about 7, , the use of a current density of $14 \mathrm{~mA} / \mathrm{cm}^{2}$, and an EC time of $125 \mathrm{~min}$, gave access to pollutants (COD, Color, $\mathrm{Cr}$, and $\mathrm{NH}_{3}-\mathrm{N}$ ) removal efficiency 67, 93, 100 and $46 \%$, respectively. And also, the energy yield of harvested hydrogen was $15 \%$ of the electrical energy demand of the electrocoagulation process. Thus, the operating costs for two cases were found to be $0.675 \$ / \mathrm{m}^{3}$ wastewater. It could be seen that hydrogen gas production coupled with pollutants removal efficiency by EC continuous mode would be an effective approach for energy recovery and wastewater reutilization.
\end{abstract}

Keywords: Tannery wastewater; Hydrogen gas recovery; continuous mode; Al/Fe electrode; Energy

\section{Introduction}

Tannery industries are among the most polluting industries in terms of the volume and the complexity of treatment of its effluents discharge. Wastewaters generated by tannery industries are known to contain large amounts of potentially toxic wastewaters containing both organic and inorganic compounds [1-4]. Tanneries effluents are also characterized by high wastewater generation in the range of $30-35 \mathrm{~L} \mathrm{Kg}^{-1}$ skin/hides process with a variable $\mathrm{pH}$, high concentration of suspended solid, BOD, chromium, COD, and sulfides as well as low biodegradability $[5,-7]$. On the other hand, the tannery industry represents an important economic sector in many countries but in parallel, the global leather industry produces about 18 billion square feet of leather a year with an estimated value of about $\$ 40$ billion [8].

There are many options that are utilized for the treatment of tannery wastewater, such as biological process $[9,10,11]$ and physical-chemical process $[6,7-12]$. In this context, the conventional biological treatment does not always achieve satisfactory performance due to the toxicity of the tannery wastewater that affects the development of the bacteria. In addition, traditional physical-chemical processes are comparatively expensive, and may lead to secondary pollution. This is because it needs additional chemicals [13]. The drawbacks mentioned above have forced various industries to seek for effective alternative treatment technologies for pollutants removal, ideally by electrochemical methods. Nowadays, electrochemical treatment methods have reached such a state that they are not only comparable with other technologies in terms of cost, but they are also more efficient and more effective [4].

Ultimately, it is a great attention to use these methods in treatment of water/wastewater owing to its attractive advantages such as environmental compatibility, versatility, energy efficiency, safety, selectivity, amenability to automation, and cost effectiveness [14]. Recently, electrochemical technologies have been investigated in environmental applications, especially for treating water/wastewater. One of these processes is electrocoagulation (EC) which has achieved much attention due to its attractive advantages as: simple, reliable, and cost-effective operation for the treatment of wastewater. In fact, it involves dissolution of metal from the anode with simultaneous formation of hydroxyl ions, and generation of hydrogen gas at the cathode which can be recovered for use as energy source or a reactant for other industrial applications [15]. There are vital advantages of EC as a low sludge production technology; secondly, the EC flocs are relatively large, contain less bound water, more stable, and amenable to filtration [16]. The fitting choice of EC materials is very essential electrode materials, generally, are aluminum and iron. They are cheap, readily available, and have been proven effective [17]. 
EC has satisfactory been utilized decades to treat wastewater of olive mill [18,19], restaurant [17], metal plating [20], domestic [21], tannery [22-25], rose processing [26], textile industry [27], etc. The continuous mode of the EC process has however been less investigated, except in a few studies [28- 34]. Based on literature reviews, so far no other studies have taken into account the aspect of hydrogen recovery from the electrocoagulation process. Hydrogen is a main by-product of the electrocoagulation process as it is generated at the cathodes by water electrolysis. With an effective gas-liquid-solid separation process, high quality hydrogen can be recovered from the electrocoagulation process and used as an energy source or as a reactant for industrial processes. The prime objective behind this study was to discuss the applicability of EC in the continuous mode to treat tannery wastewater. In this study, experiments were conducted to examine the effects of the operating parameters, such as $\mathrm{pH}$, current density, electrode material and inlet flow rate on pollutants removal .The optimal operating conditions and operating costs were determined.

\subsection{Wastewater sources and characteristics}

\section{Materials And Methods}

The samples analyzed in this work were collected from different outflow wastewaters of the Organized Tannery Industrial Region (OTIR) which is located in the Tuzla quarter of Istanbul, Turkey. With regard to OTIR, the treatment plant receives wastewater from 100 small tannery plants based on chrome and vegetables tanning. Generally, it has four treatment steps that can be given as: equalization, settling, aerobic activated sludge, and physiochemical treatment by chemical coagulation. The samples were put into PE containers, transported to laboratory in one hour, mixed very well, and conserved at $4^{\circ} \mathrm{C}$ during the experiments. The composition of the wastewater sample is presented in Table 1. The sample was collected in December 2014.

Table 1: Characteristics of raw tannery wastewater used in this study

\begin{tabular}{|l|l|}
\hline Parameter & \multicolumn{1}{|l|}{ Value } \\
\hline PH & 4.10 at $6.5^{0} \mathrm{C}$ \\
\hline Conductivity $\left(\mathrm{mS} \mathrm{cm}^{-1}\right)$ & 11.71 \\
\hline COD & 2800 \\
\hline Soluble COD & 1789 \\
\hline Suspended solids & 912 \\
\hline Chloride & 1691 \\
\hline Total chromium & 570 \\
\hline Color & 180 \\
NH3-N & \\
\hline
\end{tabular}

Note: Color ADMI (10) Pt-Co, all other parameters as $\mathrm{mgL}^{-1}$.

\subsection{Experimental set-up and the procedure}

The continuous-mode system used in electro-coagulation treatment consisted of: (1) a wastewater storage tank; (2) a peristaltic pump with an operating flow rate between 0.07 and $1140 \mathrm{ml}$ min (Longer Pump, BT300-2J, China); (3) an electrochemical reactor with a set of five pairs of iron or aluminum electrodes; (4) gas separation tank; (5) sedimentation tank. The electrochemical reactor was constructed with Plexiglas having a dimension of $5.0 \times 10.0 \times 20 \mathrm{~cm}$. It contained a set of 5 pairs of electrodes made of iron or aluminum, which reduced the working volume to $2.5 \mathrm{~L}$. The electrodes were connected vertically with a gap distance of $7 \mathrm{~mm}$. The configuration resulted in a total electrode working area of $45 \mathrm{~cm}^{2}$. The electrodes were connected in monopolar parallel mode to a DC power supply and the electrochemical reactor was operated in continuous mode. The continuous electrochemical reactor was designed to work by an up-flow process. The tannery wastewater was fed in at the bottom of the reactor, flowed upward through the layers of the electrodes and drained out at the outlet located at the top of the reactor. The pump flow rate was adjusted to control the fluid residence time according to Eq. (1):

$\mathrm{HRT}=\mathrm{V} / \mathrm{F}$,

where, HRT is the hydraulic retention time (min), $\mathrm{V}$ is the working volume of the reactor (L) and $\mathrm{F}$ is the flow rate $\left(\mathrm{L} \mathrm{min}^{-1}\right)$. In this study, the working volume $(\mathrm{V})$ was $2.5 \mathrm{~L}$. The HRT was controlled to be equal to the required electrocoagulation time. For example, if the required electrocoagulation time was 5 min, the pump flow rate was adjusted to be $500 \mathrm{ml} \mathrm{min-}{ }^{1}$. If the required electrocoagulation time was $10 \mathrm{~min}$, the pump flow rate was adjusted to be $250 \mathrm{ml} \mathrm{min}^{-1}$.

However, electrodes ( $\mathrm{Al}$ or $\mathrm{Fe})$ were immersed in the reactor containing tannery wastewater and connected to DC power supply by wires; the reactor was closed tightly by silicon to prevent any gas leakage. The tannery wastewater (TWW) was taken from different outflow wastewater of the Organized Tannery Industrial Region (OTIR) located in the Tuzla quarter of Istanbul, Turkey. The raw TWW contained nearly 2500 $-3000 \mathrm{mglL}$ of COD. Conductivity of the raw TWW was $11.71 \mathrm{mS} \mathrm{cm}^{-1}$ with an original $\mathrm{pH}$ of 4.10 . The 
applied DC voltages (V) and the amperes (A) were monitored during the course of experiments. And also, the electrical energy supplied to the system was calculated using the following equation:

$\mathrm{Ee}=\mathrm{VIt}$,

Where, Ee is the electrical energy supplied to the system by the DC power supply $(\mathrm{J})$; V is the applied DC voltage; I is the current $(\mathrm{A})$, and $\mathrm{t}(\mathrm{sec})$ is the duration of the applied DC voltage.

Pollutant removal efficiency was determined from the formula in Eq. (3):

Pollutant removal efficiency $(\%)=\frac{\mathrm{C} 0-\mathrm{Cf}}{\mathrm{C} 0} \times 100$

Produced hydrogen gas was collected in the head space of the reactor and also calculated by water displacement method. In this study, two values of $\mathrm{pH}$ for aluminum even iron electrodes were selected in order to determine the effectiveness of the electrocoagulation according to pollutants removal efficiency as well as hydrogen gas production. Additionally, the effects of the operating parameters were then studied and the optimal conditions of electrocoagulation continuous system for tannery wastewater treatment were determined. The operating parameters and conditions are summarized in table 2.

Table2: Conditions of operating parameters

\begin{tabular}{|l|l|}
\hline Operating parameter & Value \\
\hline Current density, $\mathrm{mA} / \mathrm{cm}^{2}$ & 7 and 14 \\
\hline Electrode number, pair & 5 for $\mathrm{Al}$ or $\mathrm{Fe}$ \\
\hline Electrode gap, $\mathrm{cm}$ & 0.7 \\
\hline Wastewater volume & $2.5 \mathrm{~L}$ \\
\hline Inlet flow rate, $\mathrm{ml} / \mathrm{min}$ & $17,20,25,33,50$ and 100 \\
\hline Electrocoagulation time (min) & $25,50,75,100,125$, and 150 \\
\hline Initial $\mathrm{pH}$ & $4.1,6$ for $\mathrm{Al}$ and $4.1,7$ for $\mathrm{Fe}$ electrodes \\
\hline
\end{tabular}

\subsection{Analytical procedure}

The wastewater analyses were carried out in accordance with the Standard Methods for Examination of Water and Wastewater [35]. " $\mathrm{pH}$, conductivity, COD, total chrome, and color were determined with (A Jenway 3040 brand, HACH HQ40d, closed reflux titrimetric method 5220C, A-Analyst 400, atomic absorption spectrometer, and HACH LANGE GmbH DR 5000 (spectrophotometer), respectively)". Merck analytical quality chemicals were used in the preparation of reagents.

\section{Results And Discussion}

The process standardization of electrocoagulation of tannery wastewater was carried out by studying the current density, inlet flow rate or electrolysis time and effects of $\mathrm{pH}$ solution.

\subsection{Effect of current density, inlet flow rate and energy consumption on the pollutants removal efficiency for aluminum electrodes}

In all electrochemical technologies, current density is considered a vital parameter for controlling the reaction rate within the electrochemical reactor [36]. It is well known that current density determines the production rate of coagulant, adjust also bubble production, and consequently affects the growth of flocs [28]. According to the conditions of operating parameter that listed in table 1 we investigated the effect of current density $j$, inlet flow rate and energy consumption on the efficiency of pollutants removal.

Fig.1.a and $b$ show that the time required achieving steady-state conditions, i.e. the values on the plateau region, decreased when $j$ increased from 7 to $14 \mathrm{~mA} / \mathrm{cm}^{2}$ and then became nearly constant at about 125 min. An increase in current density from 7 to $14 \mathrm{~mA} / \mathrm{cm}^{2}$ yielded an increase in the efficiency of pollutants removal, i.e. COD, color, chromium and ammonium removal efficiencies were increased from 44- 61, 81-90, 98-100, and 17-31\%, respectively. This could be anticipated: when the current density increases, the amount of $\mathrm{Al}^{3+}$ cations released by the anode and therefore of $\mathrm{Al}(\mathrm{OH})_{3}$ particles also increases.

As shown in fig.1.a and $\mathrm{b}$, in addition, energy consumption was directly proportional to applied current density. The energy consumption increased from 4.5 to $6.75 \mathrm{KWh} / \mathrm{m}^{3}$ with the increase in the applied current density. When the energy consumption was measured, the power requirement of electrocoagulation for pollutants removal was taken into account, while pumping energy was not considered.

Thus, fig.2.a and b has achieved, satisfactory, a steady state conditions. So, the values on the plateau region, decreased when $j$ increased current density from 7 to $14 \mathrm{~mA} / \mathrm{cm}^{2}$ and then became nearly constant at about $125 \mathrm{~min}$. An increase in current density from 7 to $14 \mathrm{~mA} / \mathrm{cm}^{2}$ yielded an increase in the efficiency of pollutants removal, i.e. COD, color, chromium and ammonium removal efficiencies were increased from 53-73, $85-95,100-100$, and 23-60 \%, respectively. However, the pollutants removal efficiency at $\mathrm{pH} 6$ is found superior than $\mathrm{pH} 4.1$ for aluminum electrodes. As described in fig.2.a and b, in addition, it can be seen that the energy consumption was directly proportional to applied current density. The energy consumption increased from 4.5 to $6.75 \mathrm{KWh} / \mathrm{m}^{3}$ with the increase in the applied current density. When the energy consumption was measured, the power requirement of electrocoagulation for pollutants removal was taken into account, while 
pumping energy was not considered. Conclusively, as the current density was increased, the pollutants removal efficiencies and the energy consumption increased.Regard to the inlet flow rate, as seen in (fig.1.a and b, fig.2.a.b), it was increased to $17,20,25,33,50$ and $100 \mathrm{ml} / \mathrm{min}$, the retention time directly decreased to 150 , $125,100,75,50$, and $25 \mathrm{~min}$. the pollutants removal efficiencies were decreased as the flow rate was increased. This showed that mixing by the rapid turbulent inlet to the reactor initially affected the pollutants removal efficiency. However, after the flow rate was increased somewhat, from 20 to $25 \mathrm{ml} / \mathrm{min}$ in this study, the influence of retention time decreasing was stronger than that of the mixing effect. The optimal flow rate could be considered to be $20 \mathrm{ml} / \mathrm{min}$ which is corresponding to $125 \mathrm{~min}$. The result indicated that energy consumption was independent of the inlet flow rate, which is similar with its behavior according to pollutants removal. Despite the increasing of the inlet flow rate, the power consumption remained at $4.5-6.75 \mathrm{KWh} / \mathrm{m}^{3}$ for fig. 1 .a and $\mathrm{b}$ and fig.2. $\mathrm{a}$ and $\mathrm{b}$. The pumping energy was not taken into account on integrating the energy consumption. Anyway, for the experimental conditions of Fig.1.a and b and Fig.2.a and b, optimum current density and inlet out flow seemed therefore to be $14 \mathrm{~mA} / \mathrm{cm}^{2}$, and $20 \mathrm{ml} / \mathrm{min}$, as it can be considered that $\mathrm{Y}_{\mathrm{COD}}=61,73 \%$ respectively, corresponds to the minimum acceptable value for EC process. However, fig.2.b has achieved the best condition according to our results, optimum current density, $\mathrm{pH}$ and inlet out flow or electrocoagulation time seemed therefore to be $14 \mathrm{~mA} / \mathrm{cm}^{2}, 6.0$ and $20 \mathrm{ml} / \mathrm{min}$ or $125 \mathrm{~min}$, respectively, as it can be considered that $\mathrm{Y}_{\mathrm{COD}}=73 \%$, corresponds to the minimum acceptable value for EC process. At these conditions, thus, the removal efficiency of Color, $\mathrm{Cr}$, and $\mathrm{NH}_{3}-\mathrm{N}$ was 95,100 and $51 \%$ respectively, and the energy consumption was $6.75 \mathrm{KWh} / \mathrm{m}^{3}$ in the case of aluminum electrodes.

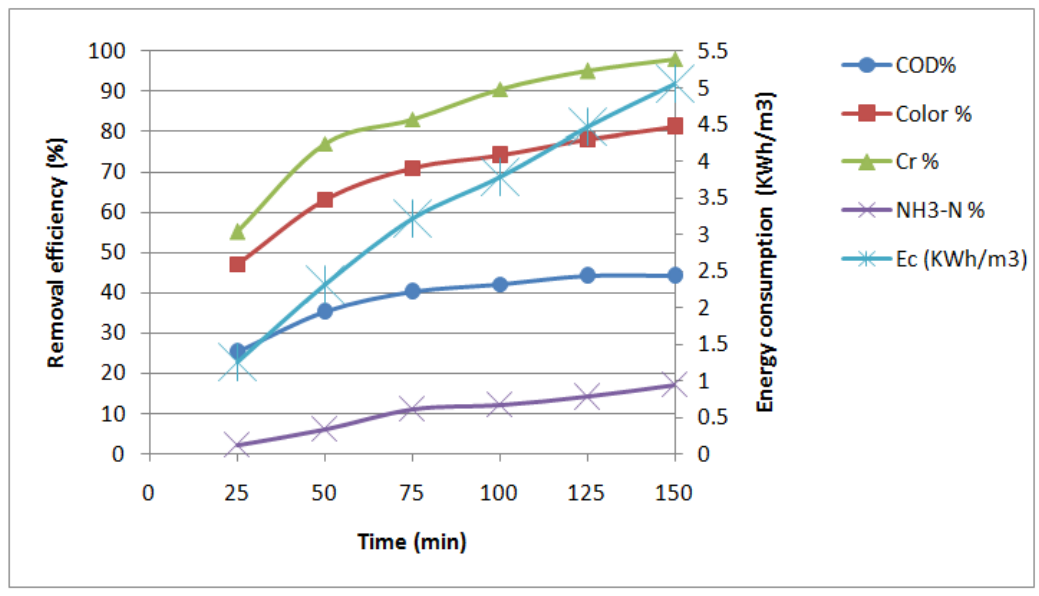

Fig.1.a. Effect of current density on pollutants removal efficiency with time or inlet flowrate and energy consumption of electrocoagulation using aluminum electrodes (original $\mathrm{pH} 4.1$, five pairs of $\mathrm{Al}$ electrodes, current density $7 \mathrm{~mA} / \mathrm{cm}^{2}$ ).

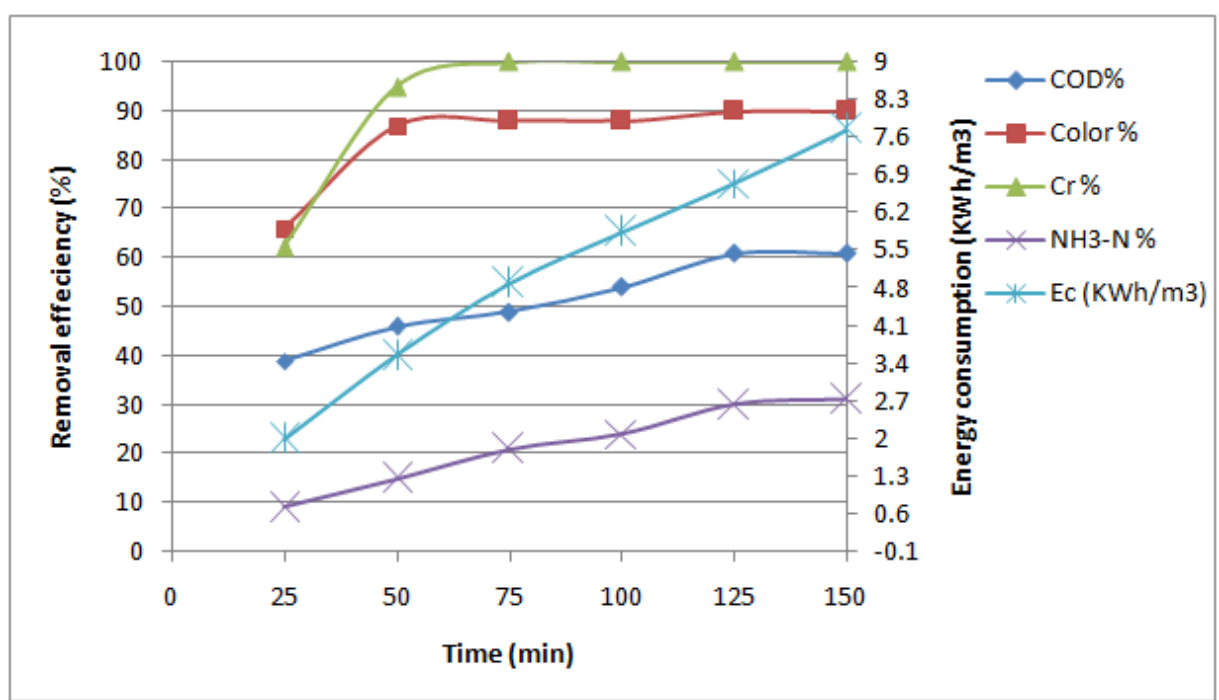

Fig.1.b. Effect of current density on pollutants removal efficiency with time or inlet flowrate and energy

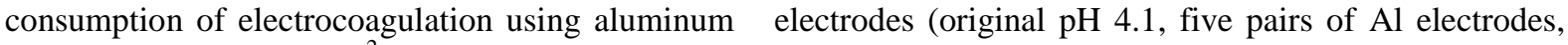
current density $14 \mathrm{~mA} / \mathrm{cm}^{2}$ ). 


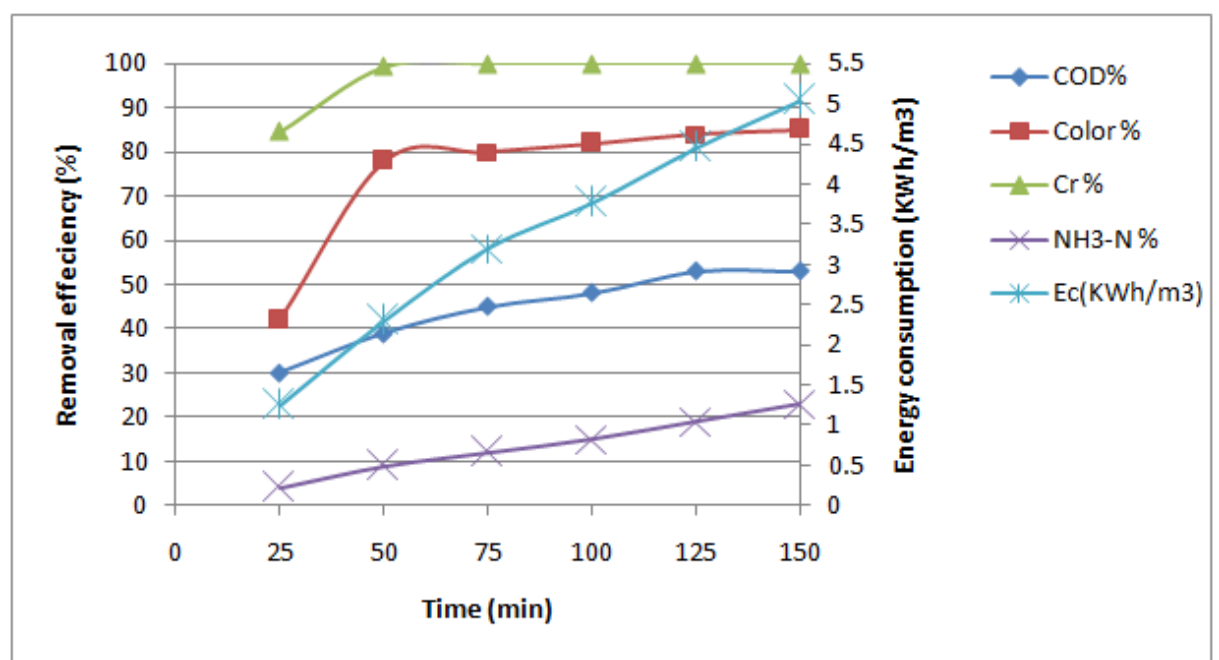

Fig.2.a.Effect of current density on pollutants removal efficiency with time or inlet fowrate and energy consumption of electrocoagulation using aluminum electrodes $(\mathrm{pH} 6$, five pairs of $\mathrm{Al}$ electrodes, current density $\left.7 \mathrm{~mA} / \mathrm{cm}^{2}\right)$.

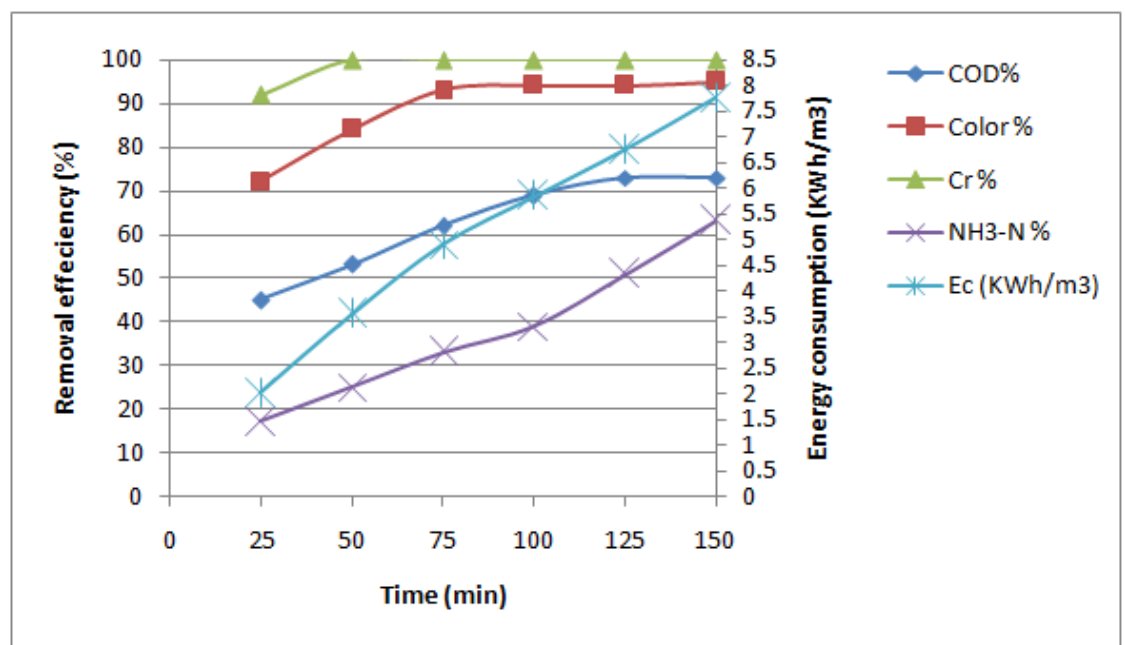

Fig.2.b.Effect of current density on pollutants removal efficiency with time or inlet flowrate and energy consumption of electrocoagulation using aluminum electrodes ( $\mathrm{pH} \mathrm{6}$, five pairs of $\mathrm{Al}$ electrodes, current density $14 \mathrm{~mA} / \mathrm{cm}^{2}$ ).

\subsection{Effect of current density, inlet flow rate and energy consumption on the pollutants removal efficiency for iron electrodes}

It is well known that current density $(j)$ is the major operating variable directly affecting on the performance of electrocoagulation process and operating costs. It is clearly evident that as the value of $j$ increases from $7-14 \mathrm{~mA} / \mathrm{cm}^{2}$ a substantial increment in the pollutants removal was observed (fig.3.a and b). Highest removal efficiency was achieved at $14 \mathrm{~mA} / \mathrm{cm}^{2}$, as it can be seen in fig.3.b. This may be due to as the value of $j$ increases, the amount of $\mathrm{Fe}^{+3}$ cations liberated by anode increases, formation of monomeric ions and hydroxyl complexes increases and thus may be attributed to the adsorption of the hydrogen bubbles produced by electrodes[37].

Anyway, figure 3.a and b show the removal efficiency of the pollutants and the energy consumption as a function of current density and electrocoagulation time or the inlet flow rate. The pollutants removal efficiency was comparable for every combination of current density and electrocoagulation time. Therefore, when considering both pollutants removal efficiency and energy demand, fig 3.b seemed to be the most suitable for treating tannery wastewater. The pollutants removal efficiencies of COD, Color, $\mathrm{Cr}$, and $\mathrm{NH} 3-\mathrm{N}$ were 53, 76, 100 and $27 \%$ respectively, and the energy demand was $8.0 \mathrm{kWh} / \mathrm{m}^{3}$. As shown in figure 3.b, When the electrocoagulation time was increased from $25 \mathrm{~min}$ to $150 \mathrm{~min}$ at a current density of $14 \mathrm{~mA} / \mathrm{cm}^{2}$, the removal efficiency of COD, Color, Cr and NH3.-N was significantly increased from 36- 53, 73-76, 98.7-100, and 12-27 $\%$ respectively, The energy demand also increased from 2.10 to $8.0 \mathrm{kWh} / \mathrm{m}^{3}$. 
Fig.4.a and b depict the removal efficiency of pollutants in term; $\mathrm{COD}$, Color, $\mathrm{Cr}$ and $\mathrm{NH}_{3}-\mathrm{N}$ and the energy consumption as a function of current density and electrocoagulation time or inlet flow rate. The pollutants removal efficiency was comparable for every combination of current density and electrocoagulation time. Therefore, when considering both COD removal efficiency and energy demand, fig.4.b seemed to be the most suitable for treating tannery wastewater. The COD removal efficiency was $67 \%$ and the energy demand was $6.8 \mathrm{kWh} / \mathrm{m}^{3}$ at $125 \mathrm{~min}$. while, in fig.4.a the removal efficiency of COD was $45 \%$ and the energy consumption was $5.05 \mathrm{KWh} / \mathrm{m}^{3}$ at $150 \mathrm{~min}$.

Regard to the inlet flow rate, as shown in (fig.3.a and b, fig.4.a.b), it was increased to 17, 20, 25, 33, 50 and $100 \mathrm{ml} / \mathrm{min}$, the retention time directly decreased to $150,125,100,75,50$, and $25 \mathrm{~min}$. the pollutants removal efficiencies were decreased as the flow rate was increased. Based in our experimental conditions, it can be seen that the optimum condition was achieved in fig.4.b, optimum current density and inlet out flow or electrocoagulation time seemed therefore to be $14 \mathrm{~mA} / \mathrm{cm}^{2}$, and $20 \mathrm{ml} / \mathrm{min}$ or $125 \mathrm{~min}$, respectively, as it can be considered that $\mathrm{Y}_{\mathrm{COD}}=67 \%$, corresponds to the minimum acceptable value for EC process. Thus, the removal efficiency of Color, $\mathrm{Cr}$, and $\mathrm{NH}_{3}-\mathrm{N}$ was 93,100 and $46 \%$ respectively, and the energy consumption was 6.8 $\mathrm{KWh} / \mathrm{m}^{3}$.

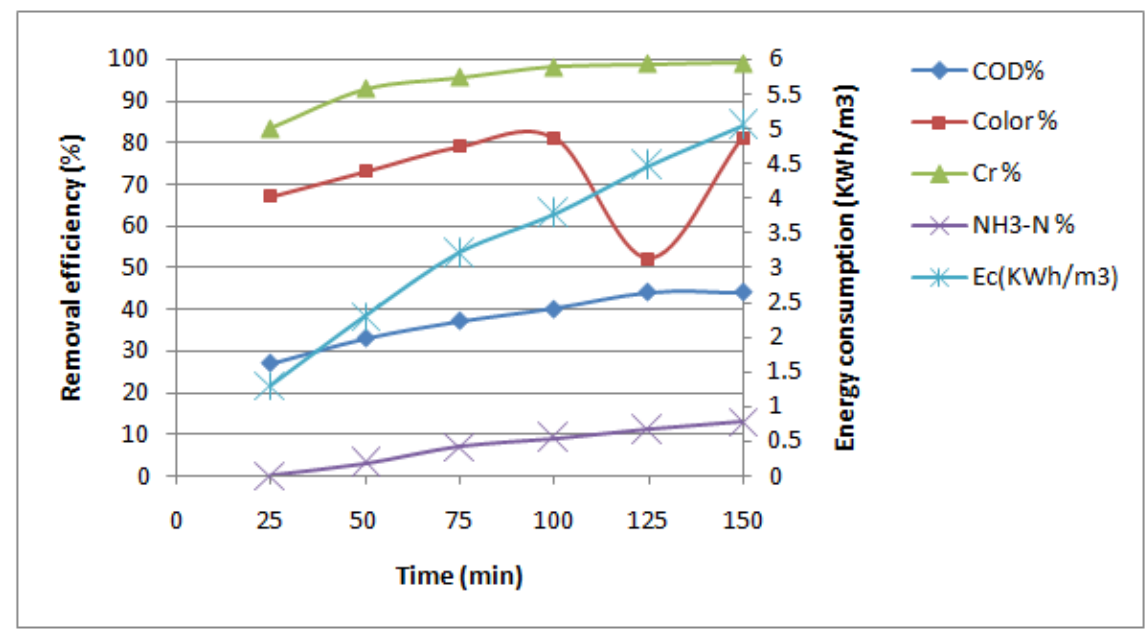

Fig.3.a. Effect of current density on pollutants removal efficiency with time and energy consumption of electrocoagulation using iron electrodes (original $\mathrm{pH} 4.1$, five pairs of electrodes, current density $7 \mathrm{~mA} / \mathrm{cm}^{2}$.

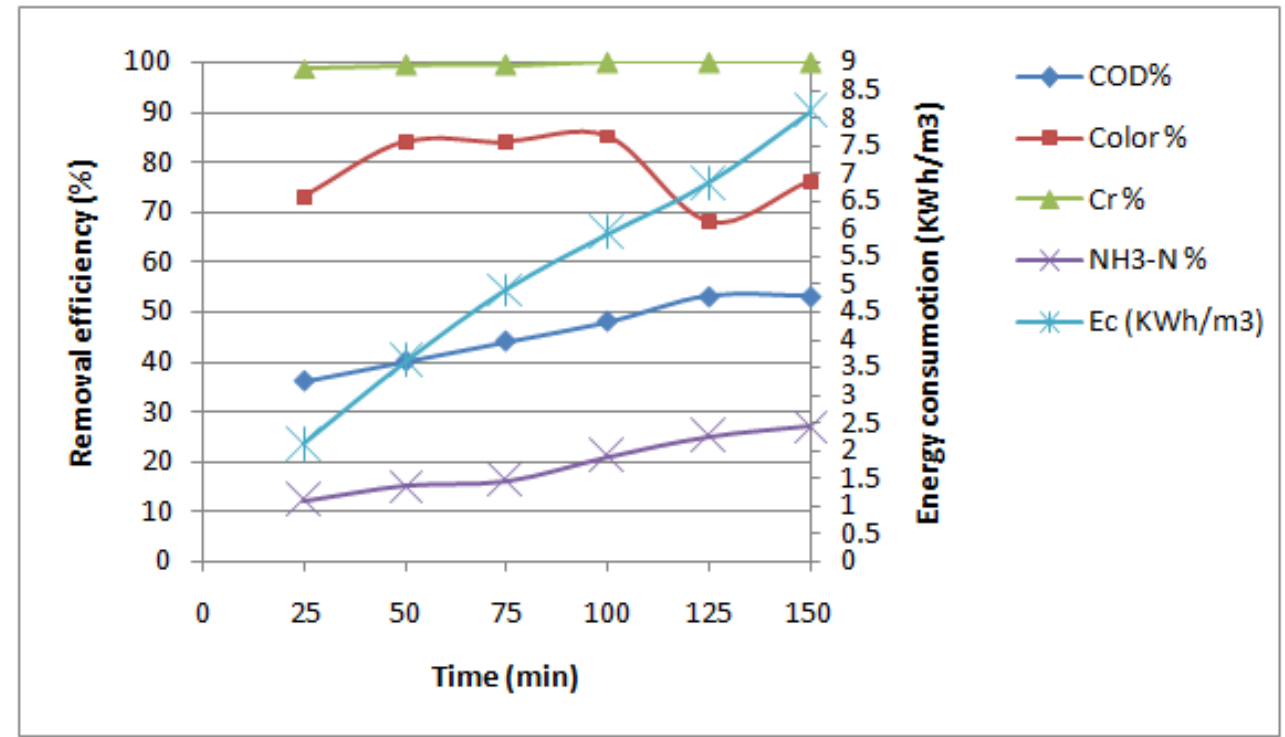

Fig.3.b. Effect of current density on pollutants removal efficiency with time and energy consumption of electrocoagulation using iron electrodes (original $\mathrm{pH} 4$.1, five pairs of electrodes, current density $14 \mathrm{~mA} / \mathrm{cm}^{2}$. 


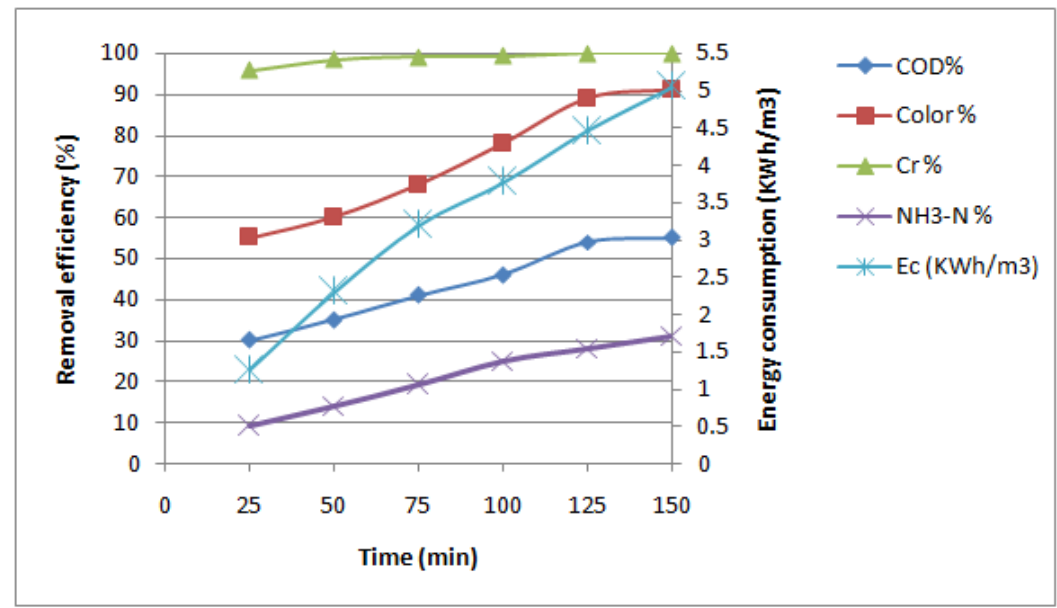

Fig.4.a.Effect of current density on pollutants removal efficiency with time and energy consumption of electrocoagulation using iron electrodes (original $\mathrm{pH} 7$, five pairs of electrodes, current density $7 \mathrm{~mA} / \mathrm{cm}^{2}$.

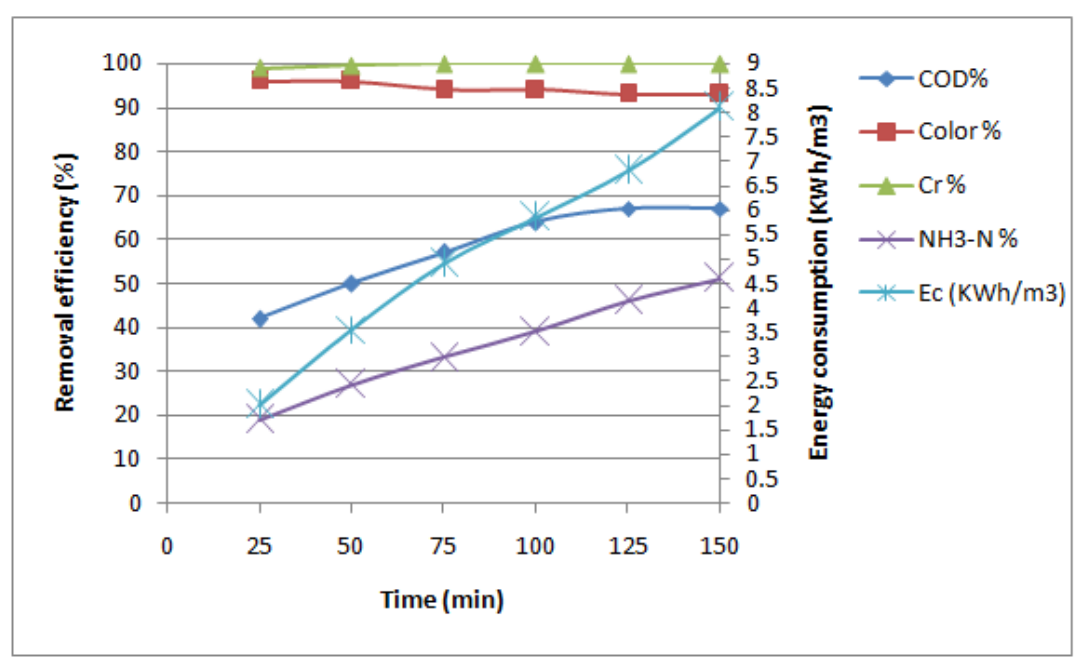

Fig.4.b. Effect of current density on pollutants removal efficiency with time and energy consumption of electrocoagulation using iron electrodes (original $\mathrm{pH}$, five pairs of electrodes, current density $14 \mathrm{~mA} / \mathrm{cm}^{2}$.

\subsection{Recovery of hydrogen and experimental and theoretical hydrogen yields}

The effluent from the electrochemical reactor was supplied continuously to the bottom of the gas separation tank, which was initially filled up with wastewater. As the wastewater is moved to the top, gas bubbles also moved up to the top together with upward effluent. The gas flowed out at the gas outlet located at the top of the gas separation tank, and water flowed out at a water outlet located near the top of the tank .With high liquid flow rates, only small amounts of solids accumulated in the gas separation tank. The amount of total gas produced was determined by water displacement method using sulfuric acid (2\%) and $\mathrm{NaCl}(10 \%)$ containing solution. The cumulative hydrogen gas production was determined by using the following equation:

$\mathrm{V}_{\mathrm{H} 2 \mathrm{i}}=\mathrm{V}_{\mathrm{H} 2 \mathrm{i}-1-1}+\mathrm{V}_{\mathrm{TG}}+\mathrm{V}_{\mathrm{G}, \mathrm{i}}-\mathrm{V}_{\mathrm{G}, \mathrm{i}-1}$

Where $\mathrm{V}_{\mathrm{H} 2, \mathrm{i}}$ and $\mathrm{V}_{\mathrm{H} 2, \mathrm{i}-1}$ are the volumes of cumulative hydrogen $(\mathrm{ml})$ calculated after the ith and the previous measurement; $\mathrm{V}_{\mathrm{TG}}$ is the total gas volume measured by the water displacement method (ml); $\mathrm{V}_{\mathrm{G}, \mathrm{i}}$ and $\mathrm{V}_{\mathrm{G}, \mathrm{i}-1}$ are the volumes of the gas in the headspace of the reactor for the ith and the previous measurement $(\mathrm{ml})$. It should be appointed out that the volume of ammonia gas has been taken into account.

Fig.5.a shows hydrogen gas evolution coupled with electrocoagulation of different current densities (7and $14 \mathrm{~mA} / \mathrm{cm}^{2}$ ) and $\mathrm{pH}$ values (4.1 and 6) for aluminum electrodes versus electrolysis time (min). As it can be seen from Fig. 5.a, the hydrogen gas production rates coupled with current density $\left(7 \mathrm{~mA} / \mathrm{cm}^{2}\right)$ and electrocoagulation time $(150 \mathrm{~min})$ were 332 and $380 \mathrm{ml}$ at ph values 4.1 and 6 , respectively. While, the hydrogen gas production rates coupled with current density $\left(14 \mathrm{~mA} / \mathrm{cm}^{2}\right)$ and electrocoagulation time $(150 \mathrm{~min})$ were 632 and $720 \mathrm{ml}$ at $\mathrm{pH}$ values 4.1 and 6 , respectively. As mentioned above, in the case of aluminum electrodes, the optimum current density and inlet out flow or electrocoagulation time seemed therefore to be 14 $\mathrm{mA} / \mathrm{cm}^{2}, \mathrm{pH} 6$ and $20 \mathrm{ml} / \mathrm{min}$ or $125 \mathrm{~min}$, respectively, as it can be considered that $\mathrm{Y}_{\mathrm{COD}}=73 \%$, and also, at these conditions it can be concluded that the hydrogen gas production rate was $582 \mathrm{ml}$. 
While, in the case of iron electrodes an investigation of hydrogen production coupled with electrocoagulatoin of two values of current density $\left(7\right.$ and $\left.14 \mathrm{~mA} / \mathrm{cm}^{2}\right)$ and $\mathrm{pH}(4.1$ and 7$)$ versus electrolysis time (min) was conducted. As it can be seen from fig.5.b the hydrogen gas production rates coupled with current density $\left(7 \mathrm{~mA} / \mathrm{cm}^{2}\right)$ and electrocoagulation time $(150 \mathrm{~min})$ were 328 and $336 \mathrm{ml}$ at $\mathrm{pH}$ values 4.1 and 7 , respectively. Thus, the hydrogen gas production rates coupled with current density $\left(14 \mathrm{~mA} / \mathrm{cm}^{2}\right)$ and electrocoagulation time $(150 \mathrm{~min})$ were 612 and $668 \mathrm{ml}$ at $\mathrm{pH}$ values 4.1 and 7 , respectively. For iron electrodes, as it can be considered that $\mathrm{Y}_{\mathrm{COD}}=67 \%$, corresponds to the minimum acceptable value for EC process. The optimum conditions were seemed therefore to be $14 \mathrm{ma} / \mathrm{cm}^{2}, \mathrm{pH} 7$ and $20 \mathrm{ml} / \mathrm{min}$ or $125 \mathrm{~min}$, thus, at these conditions it can be attained about $546 \mathrm{ml}$ of hydrogen gas.

Ultimately, it could be explained that the hydrogen gas production increased when current density increased for each electrolyte, this is because that more protons released from the anode reaction which is agree with the COD removal [38]. Beyond that, the experiments with aluminum electrodes clearly indicated that hydrogen gas production from tannery wastewater was satisfactory than iron electrodes, this is due to high free electron density and high electrical conductivity of aluminum [39].

However, the theoretical amount of hydrogen gas generated is calculated by faraday law [38];

$\eta_{\mathrm{H} 2}=\frac{I . t}{F} \cdot H$

Where, $\eta \mathrm{H} 2$ is the amount of hydrogen generated (mole), $I$ is the supplied current (Ampere), $\mathrm{t}$ is the electrocoagulation time (s), $\mathrm{F}$ is Faraday's constant (96,500 $\mathrm{C}$ per mole of electrons), $\mathrm{H}$ is the number of hydrogen molecules generated per electron involved in the redox reactions. The value of $\mathrm{H}$ is independent of the type of anode; i.e. iron or aluminum. That is, $\mathrm{H}$ is equal to $1 / 2$ in both cases. Hydrogen yield was defined as the ratio of the amount of hydrogen obtained from the experiment and the theoretical amount of hydrogen. However, it should be pointed out that the ammonia gas production has been taken into consideration.

Table 3 compares the theoretical hydrogen yield from the harvested hydrogen product and the electrical energy requirement of the electrocoagulation process. The theoretical energy yield from the harvested hydrogen was calculated based on the energy yield of hydrogen of $67.4 \mathrm{kcal} / 2 \mathrm{~g} \mathrm{H}_{2}$. (h)/ Volume $\left(\mathrm{m}^{3}\right)$. The results show that the energy yield of harvested hydrogen can reduce the electrical energy consumption of the electrocoagulation process by $11 \%$ for current density $7 \mathrm{~mA} / \mathrm{cm}^{2}$ and $16 \%$ for current density $14 \mathrm{~mA} / \mathrm{cm}^{2}$. (Assuming 50\% efficiency in hydrogen to electricity conversion).It has been noted that the choice of current densities, electrocoagulation time, $\mathrm{pH}$ and the type of electrodes, the estimated hydrogen produced is always of the same order of magnitude, ranging between 0.93 and $2.02 \mathrm{kWh} \mathrm{m}^{3}$. Besides an energy source, hydrogen can be used as a reactant in hydrogenation process to produce low molecular weight compounds, or to remove some of pollutants such a sulfur and nitrogen compound [40].

Table 3. Comparison of theoretical energy yield from harvested hydrogen product and energy consumption of the electrocoagulation process at optimum conditions.

\begin{tabular}{|l|l|l|l|l|}
\hline $\begin{array}{l}\left.\text { Current density } \mathrm{mA} / \mathrm{cm}^{2}\right) / \\
\text { electrocoagulation time }(\mathrm{min})\end{array}$ & $\mathrm{pH}$ value & Electrode type & $\begin{array}{l}\text { Experimental } \\
\text { energy production } \\
\left(\mathrm{KWh} / \mathrm{m}^{3}\right)\end{array}$ & $\begin{array}{l}\text { Experimental electrical energy } \\
\text { requirement of EC process } \\
\left(\mathrm{KWh} / \mathrm{m}^{3}\right)\end{array}$ \\
\hline $7 \mathrm{~mA} / \mathrm{cm}^{2} / 125$ & 6.0 & $\mathrm{Al}$ & 1.10 & 4.40 \\
\hline $14 \mathrm{~mA} / \mathrm{cm}^{2} / 125$ & 6.0 & $\mathrm{Al}$ & 2.02 & 6.50 \\
\hline $7 \mathrm{~mA} / \mathrm{cm}^{2} / 125$ & 7.0 & $\mathrm{Fe}$ & 0.93 & 4.46 \\
\hline $14 \mathrm{~mA} / \mathrm{cm}^{2} / 125$ & 7.0 & $\mathrm{Fe}$ & 1.90 & 6.50 \\
\hline
\end{tabular}

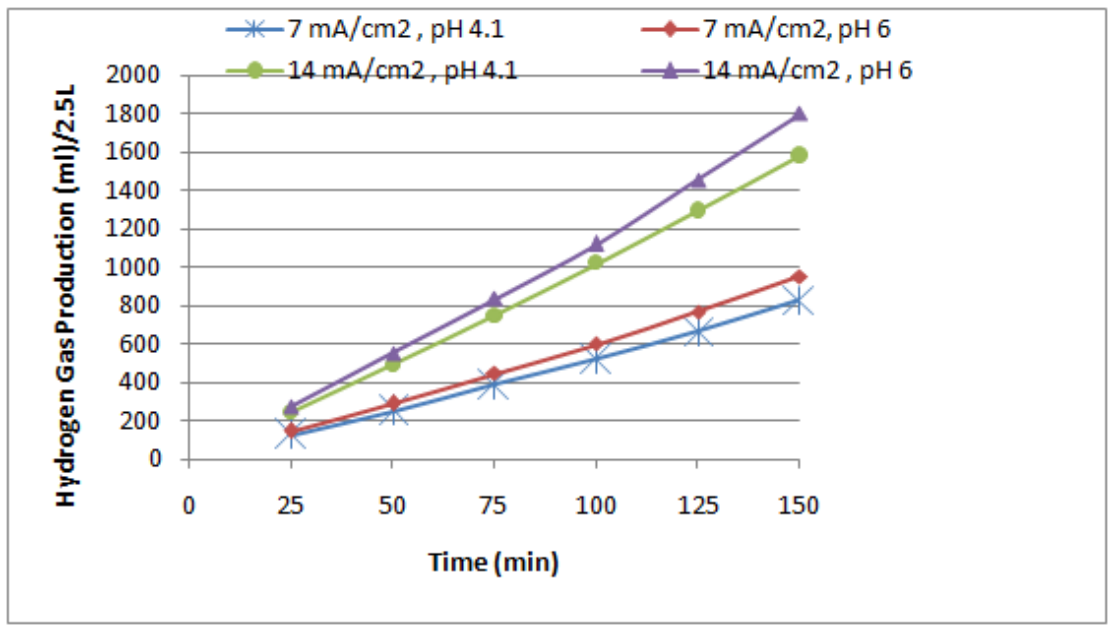

Fig.5. a Hydrogen gas production with aluminum electrodes 


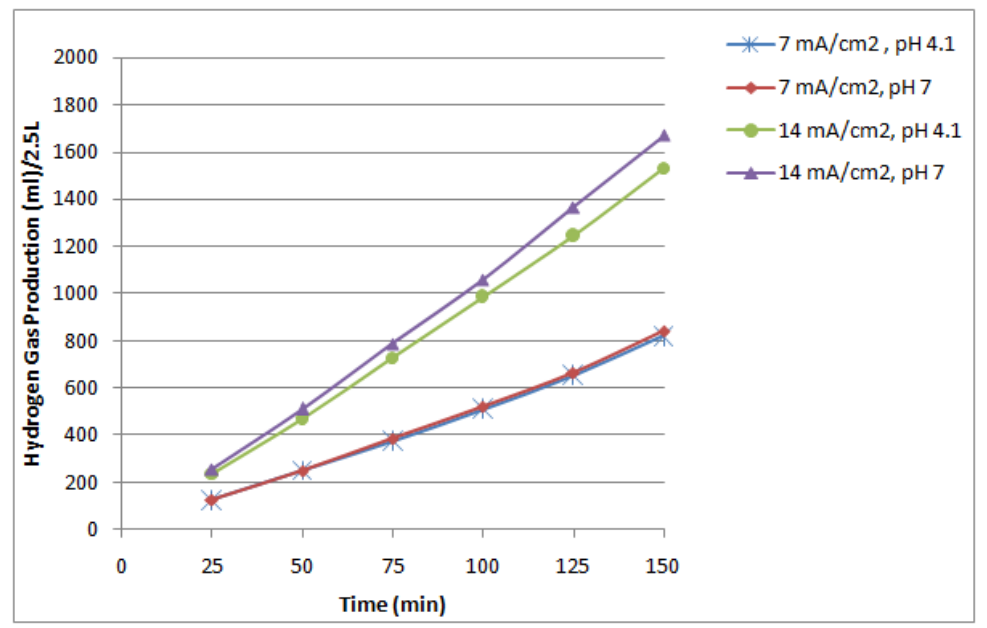

Fig.5. b Hydrogen gas production with iron electrodes

\subsection{Operating costs}

The operating cost is considered a vita parameter that affects s the implementation of any method of wastewater treatment. In this paper, the operating costs have been calculated for EC process under optimum conditions. Generally, the operating cost includes material (mainly electrodes) cost, electrical energy cost, as well as labor, maintenance, and other costs. However, in this study, the operating costs were calculated as energy consumption. Unit prices, given as Turkish market, 2015, are as electrical energy price $0.1 \$ / \mathrm{kWh}$.

The energy consumptions in the EC process were calculated via the following equations (Eqs. (5)):

Energy $_{\text {Consumption }}=\frac{I \times V \times t}{v}$

Where Energy consumption is the energy consumption $\left(\mathrm{kWh} / \mathrm{m}^{3}\right), \mathrm{V}$ is the voltage (Volts), I is the current (Amperes), $\mathrm{t}$ is the EC time (hour), and $\mathrm{v}$ is the volume of the treated wastewater $\left(\mathrm{m}^{3}\right)$.

In the two cases of aluminum or iron electrodes, the electric energy consumption and the pumping energy were taken into account for EC continuous system, the required energy amount for optimum reaction time (125 min) was $6.75 \mathrm{KWh} / \mathrm{m}^{3}$ tannery wastewater corresponding to the cost of $0.675 \$ / \mathrm{m}^{3}$ tannery wastewater.

\section{Conclusions}

A series of experiments was performed in order to find the effects of operating parameters for tannery wastewater treatment by electrocoagulation of a continuous mode. In addition, the effectiveness of electrocoagulation according to removal pollutants, i.e., $\mathrm{COD}$, Color, $\mathrm{Cr}$ and $\mathrm{NH} 3-\mathrm{N}$, was evaluated. Therefore, the significant amounts of hydrogen gas can be harvested by eclectrocoaulation has been determined. Pollutants removal by electrocoagulation was affected by current density, electrode materials, inlet flow rate, and initial $\mathrm{pH}$. Our results highlight the opportunity to apply continuous EC process for the efficient removal of pollutants ( $\mathrm{COD}$, Color, $\mathrm{Cr}$, and $\mathrm{NH}_{3}-\mathrm{N}$ ), as well as recovery of hydrogen gas from tannery wastewater at low operating costs. In the case of aluminum electrodes, at optimum conditions the results showed that for tannery wastewater with an influent $\mathrm{pH}$ adjusted at about 6 , the use of a current density of $14 \mathrm{~mA} / \mathrm{cm}^{2}$, and an EC time of $125 \mathrm{~min}$, gave access to pollutants (COD, Color, $\mathrm{Cr}$, and $\mathrm{NH}_{3}-\mathrm{N}$ ) removal efficiency $73,94,100$ and 51\%, respectively. With the above-mentioned conditions, it can be harvested a significant amounts of hydrogen gas by EC technology. In this study it can be reported that the hydrogen was lost in the liquid effluent from the gas separation tank. Ultimately, the energy yield of harvested hydrogen was $16 \%$ of the electrical energy demand of the electrocoagulation process.

In view of our results, the optimum conditions for iron electrodes were determined. With effluent $\mathrm{pH}$ adjusted at about 7 , , the use of a current density of $14 \mathrm{~mA} / \mathrm{cm}^{2}$, and an EC time of $125 \mathrm{~min}$, gave access to pollutants (COD, Color, $\mathrm{Cr}$, and $\mathrm{NH}_{3}-\mathrm{N}$ ) removal efficiency 67, 93, 100 and $46 \%$, respectively. And also, the energy yield of harvested hydrogen was $15 \%$ of the electrical energy demand of the electrocoagulation process. Ultimately, pollutants removal efficiency and hydrogen gas production were more efficiently achieved by A1 electrodes than $\mathrm{Fe}$ electrodes. This highlights the high effectiveness of continuous EC process for tannery wastewater treatment used in this work.

\section{Acknowledgment}

This study was supported by project no. (2012 -05- 02KAP02), YTU- Office of Scientific Research Project Coordination and performed in the laboratories of Environmental Engineering Department, Yildiz Technical University. 


\section{References}

[1]. L. Szpyrkowicz, G.H. Kelsall, S. N. Kaul, M. D. Faveri, Performance of electrochemical reactor for treatment of tannery wastewaters, Chem. Eng. Sci.,56 (2001) 1579 -1586.

[2]. M. Panizza , G. Cerlsola, Electrochemical Oxidation as a Final Treatment of Synthetic Tannery Wastewater, Environ. Sci. Technol. 38, (2004), 5470-5475.

[3]. A. Cassano, R. Molinari, M. Romano, E. Drioli, Treatment of aqueous effluents of the leather industry by membrane processes: A review, J. Membr. Sci., 181 (2001), 111-126.

[4]. G. Chen, Electrochemical technologies in wastewater treatment. Sep. Purif. Technol., 38 (2004), 11-41.

[5]. M.A. Aboulhassan, S. Souabi, A. Yaacoubi, Pollution reduction and biodegradability index improvement of tannery effluents, Int. J. Environ. Sci. Technol., 5, (2008), 11-16.

[6]. F.M. Menezes, R. Amal, D. Luketina, Removal of particles using coagulation and flocculation in a dynamic separator, Powder Technol., 88, (1996), 27-31.

[7]. Z. Song, C.J. Williams, R.G.J. Edyvean, Treatment of tannery wastewater by chemical coagulation, Desalination, 164 ,(2004), 249259.

[8]. A. Benhadji, M.T. Ahmed, R. Maachi, Electrocoagulation and effect of cathode materials on the removal of pollutants from tannery wastewater of Rouïba, Desalination,277,(2011), 128-134.

[9]. G. Durai, M. Rajasimman, N. Rajamohan, Kinetic studies on biodegradation of tannery wastewater in a sequential batch bioreactor, J. Biotech Res., 3 ,(2011) 19-26.

[10]. S. Dogruel, E.A. Genceli, F.G. Babuna, D. Orhon, An investigation on the optimal location of ozonation with in biological treatment for a tannery waste water, Chem. Technol. Biotechnol., 181, (2008),1877-1885.

[11]. R. Ganesh, G. Balaji, R.A. Ramanujam, Biodegradation of tannery wastewater using sequencing batch reactorrespirometric assessment, Bioresour. Technol., 97, (2006), 1815-1821.

[12]. G. Lofrano, V. Belgiorno, M. Gallo, A. Raimo, S. Meric, Toxicity reduction in leather tanning wastewater by improved coagulation, flocculation, Global Nest J. 8, (2006), 151-158.

[13]. I. Oller, S. Malato, J.A. Sa'nchez-Pe'rez, Combination of advanced oxidation processes and biological treatments for wastewater decontamination-A review, Sci. Total Environ. 409, (2011), 4141-4166.

[14]. K. Ju"ttner, U. Galla, H. Schmieder, Electrochemical approaches to environmental problems in the process industry, Electrochim. Acta., 45, (2000), 2575-2594.

[15]. C. Phalakornkule, P. Sukkasem, C. Mutchimsattha, Hydrogen recovery from the electrocoagulation treatment of dye-containing wastewater, Int. J. Hydrogen Energy,35, (2010), 10934-10943.

[16]. P. Holt, G. Barton, C. Mitchell, Electrocoagulation as wastewater treatment, The Third Annual Australian Environmental Engineering Research Event, 23-26 November, Castlemaine, Victoria, 1999, pp. 23-26.

[17]. B. G. Chen, X. Chen, P. L. Yue, Electrocoagulation and electroflotation of restaurant wastewater, J. Environ. Eng., 126, (9) (2000), (Paper No. 21505).

[18]. N. Adhoum, L. Monser, Decolourization and removal of phenolic compounds from olive mill wastewater by electrocoagulation, Chem. Eng. Process. Process Intensif., 43, (2004), 1281-1287.

[19]. U*. Tezcan U“ n, S. Ugur, A.S. Kopara, U. Bakır” Ogutveren, Electrocoagulation of olive mill wastewaters, Sep. Purif. Technol., 52, (2006), 136-141

[20]. N. Adhoum, L. Monser, N. Bellakhal, J. Belgaied, Treatment of electroplating wastewater containing Cu2+, Zn2+ and Cr(VI) by electrocoagulation, J. Hazard. Mater. 112 (2004) 207-213.

[21]. U. Kurt, M.T. Gonullu, F. Ilhan, K. Varinca, Treatment of domestic wastewater by electrocoagulation in a cell with Fe-Fe electrodes, Environ. Eng. Sci., 25(2), (2008), 153-161.

[22]. O. Apaydin, U. Kurt, M.T. Gonullu, An investigation on the treatment of tannery wastewater by electrocoagulation, Global Nest J., $11,(2009), 546-555$.

[23]. J. Feng, Y. Sun, Z. Zheng, J. Zhang, S. Li, Y. Tian, Treatment of tannery wastewater by electrocoagulation, J. Environ Sci., 19, (2007), 1409-1415.

[24]. M. Murugananthan, G. Bhaskar Raju, S. Prabhakar, Separation of pollutants from tannery effluents by electro flotation, Sep. Purif. Technol., 40, (2004), 69-75.

[25]. F.R. Espinoza-Quiñones, M.M.T. Fornari, A.N. Mo'denes, S.M. Pala'cio, F.G. da Silva, N. Szymanski, A.D. Kroumov, D.E.G. Trigueros, Pollutant removal from tannery effluent by electrocoagulation, Chem. Eng. J.,151, (2009), 59-65.

[26]. Y. Avsar, U. Kurt, T. Gonullu, Comparison of classical chemical and electrochemical processes for treating rose processing wastewater, J. Hazard. Mater., 148, (2007), 340-345.

[27]. O". Ku"csu"k, Application of Taguchi method in the optimization of dissolution of ulexite in NH4Cl solutions, Korean J. Chem Eng., 23(1), (2006), 21-27.

[28]. T. Kim, C. Parka, E. Shinb, S. Kim, Decolorization of disperse and reactive dyes by continuous electrocoagulation process, Desalination, 150, (2002) ,165-175.

[29]. M.Y.A. Mollah, P. Morkovsky, J.A.G. Gomes, M. Kesmez, J. Parga, D.L. Cocke, Fundamentals, present and future perspectives of electrocoagulation, J. Hazard. Mater, B 114, (2004), 199-210.

[30]. N. Daneshvar, H. Ashassi-Sorkhabi, A. Tizpar, Decolorization of orange II by electrocoagulation method, Sep. Purif. Technol., 31, (2003), 153-162.

[31]. N. Mameri, A.R. Yeddou, H. Lounici, D. Belhocine, H. Grib, B. Bariou, Defluoridation of septentrional of Sahara water of North Africa by electrocoagulation process using bipolar aluminum electrodes, Wat. Res., 32, (1998), 1604-1612.

[32]. X. Chen, G. Chen, P.L. Yue, Separation of pollutants from restaurant wastewater by electrocoagulation, Sep. Purif. Technol., 19, (2000), 65-76.

[33]. L. Ben Mansour, I. Ksentini, B. Elleuch, Treatment of wastewaters of paper industry by coagulation-electroflotation, Desalination, 208, (2007), 34-41.

[34]. B. Merzouk, B. Gourich, A. Sekki, K. Madani, Ch. Vial, M. Barkaoui, Studies on the decolorization of textile dye wastewater by continuous electrocoagulation process, Chem. Eng. J., 149, (2009), 207-214.

[35]. APHA, AWWA, EF, Standard Methods for the Examination of Water and Wastewater, twentieth ed., American Public Health Association, Washington, DC,1998.

[36]. M.Y.A. Mollah, P. Morkovsky, J.A.G. Gomes, M. Kesmez, J. Parga, D.L. Cocke, Fundamentals, present and future perspectives of electrocoagulation, J. Hazard. Mater., 114 ,(2004), 199-210.

[37]. N. Tyagi, S. Mathur, D. Kumar, Electrocoagulation process for textile wastewater treatment in continuous up flow reactor, J. Sci. Ind. Res., 73,(2015), 195-198. 
[38]. C. Phalakornkule, P. Sukkasem, C. Mutchimsattha, Hydrogen recovery from the electrocoagulation treatment of dye-containing wastewater, Int. J. Hydrogen Energy ,35, (2010), 10934- 10943.

[39]. F. Kargi, Comparison of different electrodes in hydrogen gas production from electrohydrolysis of wastewater organics using photovoltaic cells (PVC), International journal of hydrogen energy 36 (2011) 3450- 3456.

[40]. D. Das, T. N. Veziroglu, Hydrogen production by biological processes: a survey of literature, Int. J. Hydrogen Energy ,26, (2001), $13-28$. 